\title{
A MÉRFÖLDKŐ ELÉRKEZETT - OKOSBÓL INTELLIGENS, VÁROSBÓL ÖKOSZISZTÉMA, TUDÁSMEGOSZTÁSBÓL KONZULTÁCIÓ
}

A tanulmány célja értelmezni azt a mérföldkövet, mely az okos eszközöktől és szolgáltatásoktól átvezet a mesterséges intelligencia korai szakaszába. Ezen belül a tanulmány rávilágít azokra a jelenségekre és kérdéskörökre, melyek egyre inkább befolyásolják a kormányzati és üzleti döntéshozást, melyek ökoszisztéma-alapú megközelítései támogatják a komplex ember-gép alkotta valóság létrehozását annak felelősségi és filozófiai kérdéseivel, illetve külön tárgyalja az edukáció és az érzékenyítés szerepét a jövő-konzultációban. A tanulmányban bemutatott kutatási eredmények rámutatnak az életminőség mint legfőbb cél jelentőségére és arra is, hogy már nemcsak az ember felől merülnek fel filozófiai és episztemológiai kérdések, hanem az ember alkotta mesterséges intelligencia felől is. A tanulmány végül rövid esetekkel zárul - elsőként megvizsgálva a privát és a nyilvános adatok szerepét a megfigyelési kultúrában, ezt követően pedig elemezve a funkcionalitásra és a szórakoztatásra épülő társadalmi sci-fi konzultációs lehetőségeit. Konzekvenciaként fogalmazódik meg a tanulmány zárásaként, hogy a célul kitűzött életminőség-javítás milyen etikai és felelősségi kérdésekkel jár - már nemcsak az ember, hanem a vele egyre inkább szimbiózisban létező és már ön/kritikát is gyakorló mesterséges intelligencia számára.* Kulcsszavak: okos környezetek, mesterséges intelligencia, ökoszisztéma, edukáció, konzultáció

A digitális gazdaság - digitális állam témakörben, illetve a jövőorientált politikai és üzleti döntéshozásban kiemelt szerepet kap az okos vagy intelligenssé váló környezetek és szolgáltatások kiépítése. A kérdés az, hogy egyrészt hogyan mozdulnak el az elméleti megfontolások és a gyakorlati alkalmazások a jövőbeni megvalósítások felé, másrészt kérdés az is, hogy mennyiben felhajtóerő ebben a technológia és mennyiben az emberi tényező. A filozófiai mélységü kérdésre számos választ lelhetünk a tudományos kutatások, a szakcikkek, a projektjelentések és más dokumentumok tömegében, miközben évről évre változnak az irányadó trendek.

E tanulmány ebbe a komplex területbe enged betekintést három fö pilléren keresztül. Az első pillér rámutat azokra a nagyobb léptékü változásokra, melyek az okosként értelmezett technológiát fokozatosan intelligenssé teszik és előkészítik a következő generációs implementációkat. A második pillér elsősorban a jelen okosváros-kutatásaira épül, bemutatva röviden a legfrissebb és meghatározó elemezési kategóriákat, valamint az elmúlt néhány év globálisan legkeresettebb témáit vezetői összefoglalók és trendriportok alapján. Ez alapján kerül sor arra az értelmezésre, mely a városokkal kapcsolatos jövőbeni elképzeléseket az ökoszisztéma-építésbe sorolja. Végül, de nem utolsó sorban, a harmadik pillér az emberi tényezöre helyezi a hangsúlyt. Ez utóbbi pillér bemutatja, hogy a tudásmegosztási platformokhoz képest miért szükséges elmozdulni a párbeszéd és a konzultáció irányába, melyek részvételt, vagy akár felhatalmazást generálnak a jövő döntéshozásában, kollaboratív együttmüködéssel a kormányzati vagy üzleti döntéshozásban - a kölcsönös elköteleződés érdekében. Mindhárom pillér más és más módszertani megfontolással épül fel a trendelemzéstől a tartalmi hálózatok elemzéséig. A három pillérben össze- foglalt tanulmány célja az, hogy megrajzolja annak a komplex együttműködési és jövőépítési területnek a térképét, melyben az egyre intenzívebb ember-gép szimbiózis együttesen képvisel felelösséget.

\section{Az okos alkalmazásoktól az intelligens környezetek felé}

A mérföldkő-érzet bevezető szemléltetéséhez alapkérdésül szolgál, hogy mit nevezünk okosnak vagy intelligensnek. Szolgáltatások, termékek, rendszerek jelennek meg nap mint nap az okos vagy az intelligens címkék felragasztásával, miközben a pontos definíciók vagy akár az ezeknek megfelelő gyakorlat hiányzik. Bár a két jelző használata több mint sokoldalú már a technológiai alkalmazásokat megelőzően is, a digitális technológia elterjedésével sem ismert jelenleg olyan elfogadott vagy kanonizált definíció, mely lehorgonyozná a pontos jelentést.

Megvizsgálva az „okos” és az „intelligens” jelzők eredeti, szótári jelentését az okos esetében a hangsúly a független működésen, a gyors észjáráson, a világos és megfelelő megjelenésen van, míg az ,intelligens” jelző esszenciája a megértés, illetve a képesség arra, hogy valaki vagy valami meg tudja változtatni az állapotát, vagy cselekvését a különböző helyzetek és a múltbeli tapasztalatok alapján (en.oxforddictionaries.com). A kognitív funkciónak ebben kiemelt szerepe van: a tanulás folyamat az emberi intelligencián túl már a gépeknél is detektálható, amennyiben egyre inkább trénelhetők, mintsem programozhatók a gépek. Az a szofisztikáltság viszont, ami a pszichológiai, nyelvi és filozófiai részletekben érhető tetten egy tanulás során, a számítógépes modellek számára még kihívást jelent.

\footnotetext{
Köszönetnyilvánítás

A tanulmány a KÖFOP-2.1.2-VEKOP-15-2016-00001 "A jó kormányzást megalapozó közszolgálat-fejlesztés" program Digitális Kormányzás és Digitális Állam Kiemelt Kutatóműhely keretében, annak támogatásával készült.
} 
A gyakorlatban vagy a kutatásokban visszaköszön az a típusú megközelítés, amikor konkrét alkalmazás, implementáció vagy használat sorolja be a technológiát az okos vagy intelligens kategóriába. Megemlítve két ismertebb, friss forrást ezzel kapcsolatban, egyfelől a „,dolgok internete" szolgáltatás támogatja a megértési folyamatokat, azaz intelligensnek értelmezhető egy heterogén okos környezetben (Wanigasekera et al., 2016), másfelöl egy okos otthon egy társas együttmúködésre kifejlesztett robottal (social robot) beágyazható egy tanuló vagy intelligens környezetbe (Holthaus et al., 2016).

Figyelemreméltó és a kategóriapontosítást elősegítő megközelítésnek tekintem a fokozatosságot hangsúlyozó megközelítéseket. Ezek közül is azokat, melyekben az „okos” jelző után nem az ,intelligens” a következő kategória. Értelmezve ugyanis az egyes technológiák funkcióját, az „okos” kategória mint müködés és alkalmazkodás után inkább következhet egy kezdetleges vagy korai mesterséges intelligencia fázis, ami nem átfogóan modellezi az emberi intelligenciát, hanem egy-egy müködését szimulálja és később egyre komplexebb feladatokat hajt végre (artificial narrow intelligence, továbbiakban rövidítéssel ANI). Az ANI ebben az értelemben tehát egy kezdeti fázis a mesterséges intelligencia megalapozásához - annak első buktatóival és előnyeivel egyaránt. Ezt követően és erre építve egy átfogóbb, az emberi intelligenciához hasonló változattal számolnak a szakértők - a későbbiekben valamennyi problémamegoldási és tanulási területen (artificial general intelligence, AGI). Végül az ún. szuper mesterséges intelligencia (artificial super intelligence, ASI) prognózisa jelenik meg, melynek lényege az emberi intelligencia jelentős meghaladása, be nem látható változattal és következményekkel. Az ANI - AGI - ASI felosztás széles körben elterjedt, többféle értelmezéssel és jövőképpel (többek között Swamynathan 2017). Bár a határok e kategóriák mentén várhatóan összemosódnak és átlapolódnak, külön értelmezve segítenek megérteni a kirajzolódó okos-intelligens környezetek mérföldköveit. Ennek megfelelően az okos környezetekkel való kapcsolatában egymásra épülőnek tekinthetjük az okos alkalmazásokat és az azokból kirajzolódó, különböző összetettségü, korai, általános vagy szuper mesterséges intelligenciákat (lásd 1. ábra).

1. ábra

\section{Okosból intelligens}

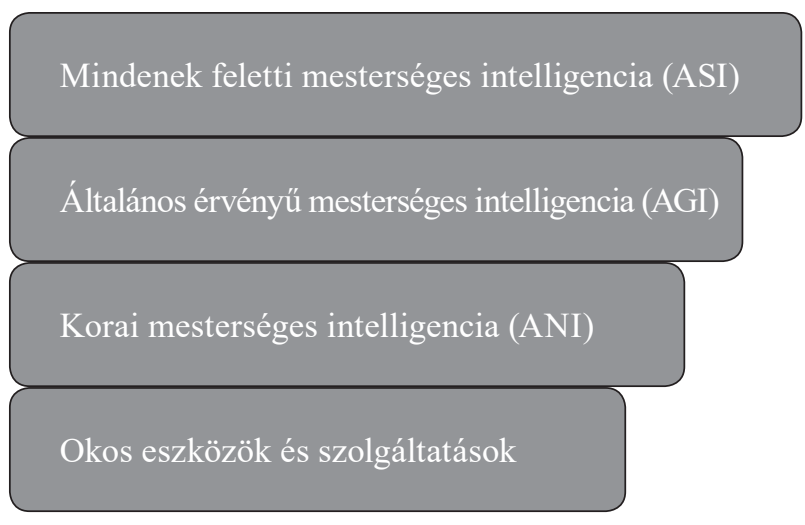

Az intenzív terjedésű dolgok internete, a felhőalapú szolgáltatások, a robotikus folyamatautomatizáció (robotic process automation=RPA) vagy a tanuló gépek és a komplex algoritmusokon alapuló adatvezérelt döntések erősen arra utalnak a legfrissebb értelmezések szerint, hogy valahol az első két mérföldkő határa elérkezett (többek között Burgess, 2018), vagyis az okos eszközök és szolgáltatások következményeként, illetve azzal párhuzamosan már a mesterséges intelligencia egyszerübb, gyenge változata is jelen van. Személyi asszisztensek vagy chatbotok detektálják a felhasználói lekérdezéseket, szükségleteket, igényeket, vagy akár a leendő preferenciákat. Önvezető autók szállítanak utasokat és árut, miközben az univerzális zenei mintázatokból vagy élő nyelvek struktúrájából a tanuló gép alkot és hoz létre új, egyedi vagy univerzális minőséget. Szofisztikáltabb változatban az IBM kognitív, az adatmintázatokat felismerő, összefüggéseket kereső és értelmező szuperszámítógépe, a Watson üzleti döntéseket hoz és ügyfélkapcsolatokat menedzsel (ibm.com/watson). A sor folytatható, ám a példákból látszik, hogy milyen eltérő területeken jelennek meg a mesterséges intelligencia korai produktumai, ami jól mutatja az irányt egy általánosabbnak vagy erősebbé váló mesterséges intelligencia felé.

Mindeközben intenzív tesztelés zajlik a mesterséges intelligencia fejlettségi szintjét illetően. A Machine Intelligence Research Institute korán felismerte, hogy a klasszikus Turing-teszt mellett egymással kombinált további, speciális teszteken is le kell futtatni a fejlesztéseket, amennyiben az emberi intelligencia jelenti az összehasonlítás alapját. Eredményeik szerint (Muehlhauser, 2013) többek között olyan komplex feladatokra van szükség, mint a kávéteszt (Goertzel et al., 2012), az egyetemi hallgató teszt (Goertzel, 2012) vagy a szakmai teszt (Nilsson, 2005). Ezekből a tesztekből ugyanis kiderül, hogy egy robot képes-e megtalálni egy házban a kávégépet és a szükséges hozzávalókkal, hogy végül főzzön egy feketét; egy mesterséges intelligencia el tud-e végezni egy kurzust egy diák helyett; avagy egy digitális avatar kiemelt fontosságú munkakörben megállja-e a helyét gazdasági területen. A tesztek teljesíthetősége mögött pedig olyan feltörekvő technológiák és fejlesztések állnak, mint a mély és gépi tanulás kombinációja, a kognitív modellek, a peremhálózati megoldások (edge computing), a kvantumszámítógépek vagy a neuromorfikus összeköttetések (Panetta, 2017) - lehetővé téve az egyre komplexebb rendszerátjárásokat. Az említett tesztek köre várhatóan kiszélesedik majd azzal, hogy egyes automatizált és tanuló rendszerek hogyan tudnak alkalmazkodni változó környezetekhez és ökoszisztémákhoz, illetve hogyan tudják előnyükre fordítani azok kondícióit.

A rövid, bemelegítésül szolgáló áttekintésből látható, hogy az okos alkalmazásokhoz képest, melyek akár hordozható vagy fix eszközökön keresztül egy információs szolgáltatási hálózatot tesznek elérhetővé, egyre komplexebb, egyre több funkciót összekötő minőségek jönnek létre. A hálózatok embereket és gépeket egyaránt összekötnek egyre felfokozottabb sebességgel és egyre több elérési ponttal. Schwab (2016) értelmezésében a behálózottság olyan fokozatra kapcsolt, ahol a technológia 
exponenciális változásokat produkál a társadalomban és a gazdaságban egyaránt. Ezen új minőségeket kiegészítve az augmentációval, a virtuális projekciókkal vagy akár a 4D nyomtatással egy olyan valóság épül, mely fokozatosan összehasonlíthatatlanná válik a digitalizáció előttivel. Egyenes következmény, hogy a percepciós vagy döntési folyamatok többé nem értelmezhetők a korábban megszokott módon. A kérdés a továbbiakban az, hogy milyen vizsgálati terület mutatja meg a maga komplexitásában a kirajzolódó mérföldkövet az okos vs. intelligens átállásban. A következő fejezet egy lehetséges választ ad erre a kérdésre.

\section{Városból ökoszisztéma}

A digitalizálódó városokról szóló diskurzusok és jelentések részletekbe menően foglalkoznak azzal, hogy a városiasodásból és a megavárosok elszaporodásából fakadó kihívásokra miként adhatók jó válaszok az okosból intelligenssé váló környezetben.

Kezdve ismét egy fogalmi megalapozással, fontos kiemelni, hogy az okos városokra nincs egy elfogadott definíció. Sőt, esetenként nem is okos, hanem kognitív, összekapcsolt (connected, lásd még „hálózatosodás” fent) városokról szólnak a viták és kutatások. Kognitív egy város abban az értelemben, hogy a müködtetéshez alkalmazott rendszerek képesek detektálni változásokat és reagálni a változásokra, sőt, arra is alkalmasak, hogy javítsanak müködések hatékonyságán és ezzel az adaptív kapacitásukat növeljék (Mostashari et al., 2011).

Visszatekintve a digitális technológia kezdeti elterjedésére, már az ezredfordulón, azaz a fentiek szerint túl korán próbálták alkalmazni a városi környezetre az intelligens jelzőt (Z. Karvalics, 2017). Ezzel együtt az „okos” elnevezés még tartja a meghatározó státuszát és ez alatt az ernyőfogalom alatt az érintett városok kialakították a maguk heterogén válaszait arra, hogy mit értenek ez alatt és merre mozdulnak el a jövőben - a közvilágítás hatékony és energiatakarékos használatától a helyi vállalkozások e-közigazgatási támogatásáig. Kritikus kérdéssé vált éppen ezért, hogy a heterogenitáson belül a fókusz a stratégián és az előnymaximalizáláson legyen (Dameri, 2017).

A stratégiai fókuszhoz és a megtérülési indikátorokhoz logikailag szükséges hozzákapcsolni azt a tényt, hogy a városok egyre inkább a gépek, robotok és digitális hálózatok helyévé és terévé válnak, ami egyúttal azt is jelenti, hogy az emberi létmód számára is átalakul egy hosszú ideig ismertnek és megszokottnak hitt rendszer és környezet. Ebben az értelemben már nem azzal mérhető vagy értékelhető egy város, egy tér vagy hely, hogy számos wifi hálózat érhető el vagy gyors az internet a felhasználói vagy gépi kapcsolatokhoz. Ennek fokozása ugyanis leginkább technológiai kérdés.

A stratégiai kérdések az összefüggő struktúrák együttes menedzselésére vonatkoznak, nevezetesen arra, hogy olyan alapfunkciókat, mint például az egészségügy, a közlekedés, az energiagazdálkodás, az élelmiszer-biztonság, az üzleti élet serkentése, az irodák müködtetése, vagy az oktatás adatosított és hálózatosított rendszerei hogyan kapcsolhatók össze a hatékonyság, az optimalizálás és a kockázatok kezelése érdekében (Fehér, 2016). Ennek következménye lehet ideális esetben a számos okosváros-stratégiában szereplő, élhető, sőt, vonzó városi környezet és a fenntarthatóan üzemeltethető város - követve a városiasodás ütemét, biztosítva alapvető szolgáltatásokat, illetve megőrizve vagy növelve a városi jóllétet. Megfelelő hatékonyság esetén az előnyök már pár éve is ezermillió dollárban voltak mérhetők évente, ami pár éven belül több mint másfél billió dollárt jelent majd - közvetlen és átfogó hatással a kormányzati költségvetésekre, a gazdaságra és a társadalomra (többek között bofaml.com 2017; McKinsey \& Company, 2015).

Az intelligens környezetek kezdetleges formái már a városok változó dinamikáját is figyelembe veszik az agilis városmenedzsment-döntéseknél. Eszerint az élet jelentős területeit felölelő és meghatározó technológiákkal olyan ökoszisztémák hozhatók létre, melyek egyaránt terveznek az élő és az élettelen befolyásoló tényezőkkel - egyfajta közös áramlásban. A technológia előnyei így fordíthatók a közösségek és az emberi hálózatok javára, míg az emberi elköteleződés vagy elutasítás így adhat inspirációt a következő fejlesztésekhez és tervezésekhez. Sőt, a tanuló vagy mély elemzést végző gépek így juthatnak el egyfajta komplex megértési kerethez.

Seel (2012) megközelítésében a társadalom és a technológia találkozása egy dinamikus együttmüködés, egyik sem létezik a másik visszacsatolása nélkül, s egyre erősebben elmozdul a kibernetikai meghatározottság felé. Kiegészítve egy metaforával, a dinamizmus forgószélként működik, kölcsönhatásban a meglévő infrastruktúrákkal, a gazdasággal, a társas-társadalmi kihívásokkal és a környezettel. Amit felkap, azt sodorja magával (bofaml.com, 2017). A smart grid mindent lefedő elektromos hálózata jó példa arra, hogyan válik egy rácsszerkezet-modell mindent lefedő alapinfrastruktúrává, miközben az összekapcsoltság egyre intenzívebb formáira is még heterogén módon reflektálnak a felhasználói csoportok. Ha elfogadjuk Seel nézetét, világosan látható, hogy az intelligens rendszerek implementálásához elengedhetetlenné vált az ökoszisztémát feltételező és építő szemlélet.

Az ökoszisztémaként történő értelmezéshez a Huawei elemzése szerint három lépcsőben juthatunk el (Huawei, 2016). Az első lépcső maga a technológia. A technológia mögött nyilván az emberi tényező is ott áll, de már csak részben, köszönhetően az automatizációnak, a tanuló gépeknek és más innovációknak. A technológiához pedig tartoznak egyrészt olyan fizikai objektumok, mint a hardware, de alapvetően a digitális technológiát leíró olyan tényezők alkotják, mint az adatrobbanás, vagy a felhőalapú adattárolás és a mobil eszközök. A minőségi ugrást, azaz a második lépcsőt a platformmá válás jelenti, melyben a nyílt forráskód, illetve a nyílt adatforrások, a fizikai és szellemi rugalmasság és a biztonság meghatározóak. Erről a lépcsőről lehet fellépni a legfelső, harmadikra, mely a standardokra épülő ökoszisztéma komplex szintje, ahol a part- 
nerség és a fejlesztés egyszerre van jelen humán és technológiai oldalról is.

$\mathrm{Az}$ okosodó, egyre intelligensebbé váló városok esetén jól látható az elmozdulás. Rövid illusztrációként ehhez érdemes itt bemutatni egy globális merítésü tartalomelemzést kumulált, rövid távra visszatekintő adatokkal - és összevetni a tanulmány írásakor érvényes legfrissebb, a fenti okos vs. intelligens dichotómiához szorosan kapcsolódó kategóriákkal.

Kezdve a rövid távra visszatekintő, kumulált adatokkal, az elmúlt három év kiemelt százötven dokumentumának elemzésére került sor a témához leginkább illeszkedő és a legtöbbet kattintott vagy hivatkozott globális keresőmotor-eredmények alapján. Ezek a dokumentumok az esetek többségében vezetői összefoglalók, kollaboratív projektelemzések és trendriportok. Nagyobb szórással olyan, kapcsolódó összefoglalók is ide tartoznak, mint a piaci elemzések, az implementációs jelentések, az ipari agendák, az innovációs tervek, a közszolgálati jelentések, a tervdokumentumok, és a legnagyobb érdeklődésre számot tartó csúcstalálkozók összefoglalói. A kapott eredmények módszertanilag szövegelemzéssel és a szövegek kapcsolathálóinak vizsgálatával születtek meg, többek között a WORDij, Gephi 0.9.1 és a Force Atlas szoftverek felhasználásával. A gyakoriságelemzés, a szópárok vizsgálata és jelentéshálók centrumainak és perifériáinak megállapításával átfogó képet kaphattunk a közelmúlt és a jelen fókuszált, stratégiai és gyakorlati területeiről (lásd részletezve: Fehér, 2017).

A kapott eredményeket az okos vs. intelligens paradigmaváltás szerint vizsgálva elmondható, hogy az „okos” kulcsszó még mindig messze meghaladta és meghaladja az, ,intelligens” jelzőt. Ami mindkettő eszközeként erősen kiemelt szerepet kap, az az adatrobbanás vagy a nyílt adatszolgáltatások (open data service/ platform) és a technológia széles körü alkalmazása a városfejlesztésben. A döntéshozás és az irányelvek megadása a kormányzatok kezében van elsősorban, de szoros együttműködésben az üzleti döntésekkel. A kérdések itt jellemzően a big data, a technológiaalapú társadalom, illetve a városmüködéssel kapcsolatos kompetenciák, felkészültségek, finanszírozási konfliktusok és érdekkapcsolatok mentén merülnek fel. Nevezetesen, menynyiben koherens egy stratégiai megközelítés, mennyire tekinthető hosszabb távú tervezésnek, vagy esetleg adott összefonódások, változó kondíciójú finanszírozások mentén születő, akár ad hoc döntéseknek.

A célkitűzések közül a legtöbbször az „életminőség" szerepel, ami humán szempontból biztató az okosból intelligenssé váló környezetek esetén. A legtöbb dilemma a magán vs. nyilvános dichotómiában jelenik meg. Részletezve, a legelgondolkodtatóbb kérdések az adatosításból és a szolgáltatási környezetek egyre inkább ökoszisztémában történő hálózatából fakadnak, ahol egyre több felhasználói vagy intézményesített résztvevő járul hozzá egyre összetettebb rendszerek müködtetéséhez. Egy példát említve, az energiagazdálkodás a lét szinte valamennyi aspektusában optimalizálandó - a munkaerő-piactól a háztartásokig. Az ezzel összefüg- gésben keringő adatok viszont egyfelöl sérülékennyé teszik az adott rendszert és annak felhasználóit, másfelől egyre nehezebb lesz meghatározni, mi számít közérdekü adatnak és mi nem (erről a kérdéskörről még lesz szó a következő fejezetben).

Külön vizsgáltuk a „városból ökoszisztéma” kérdéskörben a legfrissebb elemzéseket népszerüségük, webes hivatkozásaik, módszertani megalapozottságuk alapján. Azokat a kategóriákat kerestük, melyek jelenleg definiálják vagy rangsorolják az okosból intelligenssé váló városokat. A globális keresők szerint az írás időszakában az egyik legjobban referált és leginkább keresett az Easy Park Group ötszáz várost elemző összefoglalója, mely független forrásokat vesz alapul, módszertana is figyelemreméltó, valamint tartalmi felépítését tekintve is összehasonlítható a fent röviden elemzett dokumentumokkal (easyparkgroup.com/smart-cities-index). Emellett a digitális infrastruktúrából kiinduló elemzése kapcsolta össze leginkább tematikailag a dokumentumot az itt megjelenő okfejtéssel.

Az Easy Park Group az ENSZ Humán Fejlettségi Mutatóját és jóléti listáját, valamint az Európai Bizottság Digitális Városindexét vette alapul a fejlettebb városok körének megállapításához. A listák összevetése alapján száz várost elemzett és tizenkilenc értelmező kategóriát állított fel az okos vagy intelligens város témakörben, ahol a digitális infrastruktúra fejlettsége kiemelt hangsúllyal szerepelt. A városokról és a városok részletes elemzéséről, illetve rangsoráról itt most nem lesz szó tekintettel arra, hogy a cikk elméleti következtetésekre és nem az egy-két éven belül megváltozó rangsorokra fókuszál. A kapott eredményeket összefoglalva a következő alapvető kategóriák mentén elemezték a különböző városokat: digitalizáció, életminőség, fenntarthatóság, kormányzás, innovációgazdaság, közlekedés és mobilitás, szakértői megítélés. Ezek azok a fókuszált területek és egyben indikátorok, melyek jelenleg meghatározóak, illetve egy digitalizáció és optimalizáció mentén gondolkodó stratégiában megkerülhetetlenné váltak. Fontos megjegyezni, hogy ezek a kategóriák azért is tanulságosak, mert humán fejlettségi mutatóval és jóléti index alapján dolgoznak, azaz a társadalom szövetét, az embert és intézményesített világát veszik alapul.

Ha ebböl indulunk ki, a kérdés a következő: a mesterséges intelligencia által kialakított környezetekhez milyen irányítási és müködési indikátorok rendelhetők? Másként megfogalmazva, ha az okos városból egy emberi és mesterséges intelligencia által együttesen létrehozott ökoszisztéma jön létre, milyen kategóriák írhatják le egy város vagy egy ember-gép életvilág müködését?

Összehasonlítva a fent bemutatott szövegelemzés és a kategóriaállítás eredményeit, a jelenből egy alap, egy müködés és egy cél meghatározó. A digitalizálódó technológia és a big datára épülő adatvezérelt gondolkodás fejlettségi szintje határozza meg az alapokat a társadalom, az üzlet és a kultúra számára. A müködés alapvetően a kormányzati döntésektől függ, míg az életminőség egyszerre jelenik meg elvont és gyakorlati célként (lásd 2. ábra) 


\section{Ember-gép környezetekből közös ökoszisztéma}

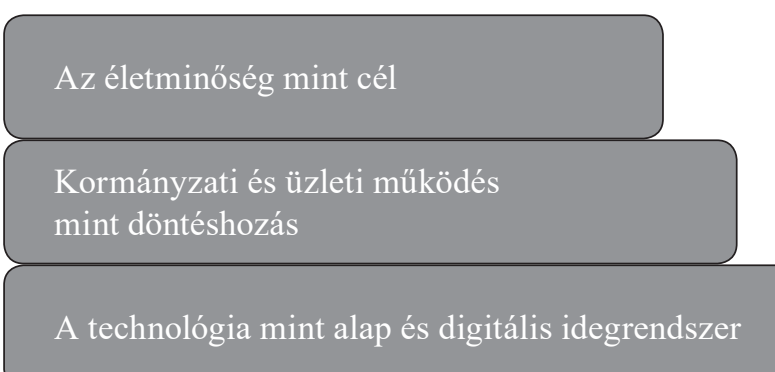

A technológiai alapokról elindulva a digitalizáció és az azzal járó adatrobbanás, a felhőalapú IoT hálózatok és más kapcsolódó szolgáltatások (Petrolo et al., 2017) meghatározóak. Ami ezen elemzésekben eddig nem szerepelt, holott feltörekvő technológiaként vagy következményként jól látható a helyük, ezek a robotika, az immerzív vagy augmentált megoldások és az egymást átjáró technológiák.

Kezdve a robotikával, már nemcsak a gyárak vagy a mezőgazdaság két vagy három dimenzióban látó, éjjel-nappal dolgozó szolgáltatásairól beszélünk (Ford, 2016). Megjelentek az elöregedő társadalmat segítö, önmüködő környezetek olyan robotokkal, melyek egyre inkább támogatják vagy helyettesítik az otthoni munkavégzést, tanácsokat adnak az új technológia használatához, internetes távirányítással működnek a világ bármely pontjáról, vagy akár a gyermekek házifeladat-készítését is támogatják (Ericsson Consumer Lab, 2015). A virtuális és augmentált környezetek, az új média és a szimuláció ehhez szövődő, tömeges elterjedése a kapuban van az alkalmazási lehetőségek felismerésével (Hype Cycle for Emerging Technologies, 2017; gartner.com; Fehér, 2016).

A felsorolt technológiák kétféleképpen kapcsolódnak egymáshoz. Egyfelől egymást inspirálják, miközben beteljesítik Moore törvényét (1965) az exponenciális technológiai növekedéssel. Másfelől egyre több módon szövődnek össze egy komplex digitális idegrendszerré (Dold - Groopman, 2017) - lehetővé téve a mesterséges intelligencia fent bemutatott mérföldköveinek megvalósulását egy elemeiben és huzalozásaikban is egymástól függö, egyre kiterjedtebb ökoszisztémával. Nemcsak adatvezérelt módon rajzolják ki egyes jövőforgatókönyvek mintázatát vagy jósolnak meg viselkedésformákat, hanem saját képzeletvilágot tudnak létrehozni és akár önkritikát is tudnak gyakorolni tanulási és alkalmazkodási folyamataik során (Ford, 2016). Ez az irány már az általános mesterséges intelligencia (AGI) felé mutat.

Ezen a ponton szükséges belátni, hogy a mai és a közeljövőben várható technológiának két ága bontakozik ki. Az egyik az ember-gép együttmüködésről vagy szimbiózisról szól. Példaként említhető, hogy autógyári munkások virtuális környezetben tanulják, hogy élesben hogyan müködjenek együtt robotokkal a gyártási folyamatban (VR-Reel, 2017). Egy másik irány a gép-gép együttműködés, amit jelenleg az M2M (machine to machine) rövidítés ír le. Lényege, hogy a gépek egymással kommunikálnak, automatizálnak, együttmüködéseket hoznak létre közvetlen összekapcsoltságban és dinamikusan hoznak döntéseket (Edson, 2015). Mindkét kimenet többféle lehetséges forgatókönyvet hordoz magában - a science fiction müfajában ismert utópiáktól a disztópiákig.

Fontos leszögezni azonban, hogy a lehetséges szcenáriókról egy bizonyos pontig, talán a gépek által felgyorsított, az emberi érzékelésen túli sebességgel működő környezetek szingularitásig (többek között Martin, 2009; Kurzweil, 2006) még részben vagy egészben mi, humán egyedek hozzuk meg a mérvadó döntéseket. A városi környezetek kialakítása ebben meghatározó szerepet játszik, ha elfogadjuk a prognózist, mely szerint a Föld lakosságának több mint kétharmada él majd városokban 2050-re (Zhang, 2016). Másik oldalról további ember-gép környezetekre is kiterjeszthetők a föbb kategóriák, úgymint technológia, döntéshozás és az ezek előtt vagy felett álló célok.

Hogyan és mihez mérten lehet reflektálni társadalmi és emberi nézőpontból a technológiai evolúcióra és annak fent nevezett következményeire? Mivel a működés ökoszisztéma szintü, ezért a kormányzati és az üzleti döntésektől egyaránt függnek a lehetséges kimenetek, illetve az életminőség egyszerre válik egy ember-gép dinamikává és ezzel együtt filozófiai-morális kérdéssé. A következő alfejezet azzal foglalkozik, hogy mennyiben érvényes vagy hatékony a tudásmegosztás vagy a konzultáció az okos-intelligens ökoszisztémában.

\section{Tudásmegosztásból konzultáció}

A tudásmegosztás és a nyílt platform hívószóvá váltak a digitalizáció, az adatrobbanás és az okos eszközök, illetve szolgáltatások hatására (többek között Arpaci - Baloğlub, 2015), s olyan folyamatokat, illetve előnyöket írnak le, mint a tanuló szervezetek működése, az ösztönző és bevonó projektek vagy a részvételi és megosztási kultúra ahol az együttműködés lehetősége felülírja a résztvevők érdekeit, s a formális, illetve az informális kollaboráció elönyt élvez.

Mára azonban nyilvánvalóvá vált, hogy a tömeges információelérés, a szabad-hozzáférésű adatok és tartalmak, sőt, az algoritmusalapú hamis hírek és az igazság utáni korszak (Fehér - Király, 2017) átrajzolta a tudásnak azon térképét, melyet a klasszikus tudáselsajátításból ismerünk. Emellett óriási tömegben érhetők el strukturálatlan és felhasználás nélküli adatok, inaktív webhelyek és a digitális szemét legkülönbözőbb formái - akár a teljes digitális gazdaság és kultúra nyolcvan százaléka, többek között a gyors elévülésnek és az új trendek felülíró szerepének köszönhetően (többek között internetlivestats.com 2017; Mayer-Schönberge - Cukier, 2014).

A kialakulóban lévő mesterségesintelligencia-alkalmazások számára és a digitális idegrendszer alapú ökoszisztémák felől közelítve éppen ezért a statikus nézőpontból a dinamikus nézőpontra történő váltás javasolt. Dinamikus annyiban, hogy szelektáló és interaktív konzultációra van szükség a tudásmegosztás kiemelt hálózati csomópontjaiban, meghatározva az önszabályozó, kollaboratív és felhatalmazó megoldásokat. Az interaktivitás ebben az értelemben már az ember és a gép, azaz az emberi és a 
mesterséges intelligencia közös felelössége - amennyiben a fentiek alapján elfogadjuk, hogy filozófiai értelemben az ember által létrehozott, programozott, trénelt, tanulásra és önkritikára is ösztönzött mesterséges intelligenciának mint következménynek is van társult felelőssége.

Megvizsgálva egy esetet, a kínai City Brain projekt (http://smartcityhub.com) Hangzhou kilencmilliós városában jött létre, az Alibaba és a Foxconn vállalatokkal együttműködésben. Az itt élőket egy kezdeti mesterségesintelligencia-fejlesztés követi nyomon a közösségimédia-aktivitástól a közlekedésig és a bevásárlásig. Emellett a vízellátástól kezdve több közmü és közszolgálat megfigyelése is zajlik egyfajta neurális hálózatként. Az eredmény a város vezetésének jelentése szerint pozitív: a nyilvános és privát adatok közös kezelése és a mesterséges intelligencia alkalmazása a döntéshozásban lehetővé teszi, hogy olyan területeken érnek el változásokat, mint a közúti balesetek számának csökkentése vagy a bünelkövetés visszaszorítása. A projekt valós időben kezel rendkívüli helyzeteket. Özönvízszerü esőzések esetén például kapcsolatot tart a lakossággal mobilszolgáltatáson keresztül, s ebbe a helyiek interaktívan kapcsolódhatnak be vagy hozhatnak saját döntéseket. A projekt hangsúlyozza, hogy azért van lehetőség a nyilvános és privát hálózatokat összekapcsoló, városi ökoszisztéma létrehozására, mert Kínában a polgárok kevésbé aggódnak a személyes adatok és a privát szféra védelme miatt.

A kérdés ezen a ponton az, hogy decentralizációról vagy szubszidiaritásról van-e szó, ahol a döntési jogosítványok delegálhatók (Nemeslaki, 2014), avagy egy megfigyelési és felügyeleti kultúráról. Két alapvető irány rajzolódik ki ugyanis. Az egyik a digitális ideghálózat, ami egy olyan dinamikus interkonnektivitást ír le, ahol nincsenek állandó csomópontok (hubok), s valóban kollaborálhatnak a társadalom legkülönbözőbb szereplői, valóban konzultálhatnak például egy város lakói környezetük fejlesztéseiről, s valóban befogadja egy kormányzati vagy üzleti döntéshozást reprezentáló gép a polgári, vagy szervezeti indítványokat. A másik irány szerint olyan megfigyelési környezetek rögzülnek, melyek hierarchikus döntési folyamataiban emberek és gépek egyaránt figyelik vagy felügyelik egymást, hogy megvédjék vagy befolyásolják a társadalom tagjait (Lyon, 2007), vagy az őket képviselő gépeket és digitális szolgáltatásokat.

Ha az utóbbi megközelítést vesszük alapul, akkor elsősorban a magánszféra védelme és más etikai kérdések merülnek fel, hiszen alapértelmezésben a privát szféra az emberi méltósághoz és autonómiához, a testi és a mentális folyamatok önrendelkezéséhez, illetve a véleményszabadsághoz, vagy a másiktól való függetlenséghez tartozik (Fehér, 2016). Seel (2012) megközelítését érdemes itt megfontolni, mely szerint a magánélet vagy a privát szféra védelme nem arról szól, hogy el kell rejtőzni vagy valamit el kell rejteni. Arról szól, hogy mindenkinek joga van tudni, kik és miért gyüjtenek adatokat róla, mit takar pontosan egy szolgáltatás és mit vár ellenszolgáltatásként, vagy mik lehetnek a visszaélés lehetőségei. Folytatva Seel gondolatait, ez az információs alapjog a mesterséges intelligenciára is kiterjeszthetö, azaz az ANI vagy AI is kontrollálhatja a saját adattermelését más rendszerekkel összefüggésben.

Ha mindezt figyelembe vesszük, két lépcsőben érdemes az aktuális és dinamikusan változó trendek alapján élni a konzultáció lehetőségeivel. Az első lépés az edukáció, a második az edukációra építő konzultáció és a kollaboráció.

Az edukációban elsősorban a kormányzati, üzleti és egyetemi kutatási közös együttmúködései meghatározóak a fent bemutatott dokumentumkutatás eredményei alapján. A szöveghálózatok elemzésekor világosan kirajzolódott, hogy ebben az együttmüködési keretben találhatók meg elsősorban azok az innovációk, melyekhez az okos városok esetén a városlakók aktivitása, érdeklődése vagy elköteleződése bekapcsolható. A közösségek és helyi érdekeltségek bevonásával a szélesebb társadalmi rétegek is elérhetővé válnak, így közvetíthető a technológiával és annak következményeivel kapcsolatos tudás. Söt, ezek azok a közös kutatási keretek, melyek létrehozzák a viszszacsatolás különböző változatait is azzal, hogy az edukáció során kiderülnek, milyen területeken vannak például fehér foltok a digitális írástudásban.

Az edukációban a szó szoros értelemben vett oktatási intézmények, szakmai továbbképző központok és a kapcsolódó tréningek is kiemelt szerepet kapnak, amennyiben megjelennek olyan aktorok, mint a produktivitás-konzultánsok, adatvédelmi tanácsadók, kutatási ügynökök (Fehér, 2016), illetve olyan előremutató kurrikulumok vagy átképzések válnak elérhetővé, mint a növekedéshekkelés, az agilis vezetés vagy a mesterséges intelligencia stratégiai elemzése. Különösen aktuális e feltörekvő területek oktatása az innovátorok és döntéshozók számára, hiszen számos új, a digitális szolgáltatásokhoz kapcsolódó szakma jelenik meg, mint például az adattudós vagy virtuális valóság dizájner. Söt, egyes üzleti elemzések szerint egyre több alkalmazottnak lesz robot fönöke vagy alkalmazottja (Kiulian, 2017), ami a mesterséges intelligenciával való együttmüködést és a gépek megértését teszi szükségessé - episztemológiai értelemben is.

Másik oldalról az edukáció érzékenyítés (Soane et al., 2012). Megértési, tanulási és alkalmazási folyamat egyszerre, ami a digitális technológiai alapú, átrendeződő társadalom és kultúra következményeit, előnyeit és hátrányait egyaránt megmutatja. Kiemelendö esete a nagykövetek alkalmazása egy-egy új, összetett szolgáltatás bevezetésénél. Az elektromos és/vagy önvezető autók kölcsönzése, telekocsi jellegű használata, alkalmazáson keresztüli használhatósága és a szó legszorosabb értelemében vett utazóközösség létrehozása a meglévő, helyi kapcsolathálózatokra épül, melyet az adott területen elkötelezett, tájékozott és értő aktorok, szervezetek vagy intézmények képesek bevezetni. Ök azok, akik a gyakorlat nyelvére le tudják fordítani a fenntarthatósági elveket és a közös előnyöket - a hozzájuk kapcsolódó közös felelősségi szintekkel együtt.

Itt érdemes megfogalmazni a konzultáció jelentőségét. Amennyiben létrejön ugyanis az edukációra építő konzultáció és kollaboráció, a gyorsan változó embergép környezetekben a lehetséges válaszok, problémake- 
zelések, implementációk és kockázatcsökkentési módok szélesebb tárháza lesz elérhető. Nem egyszerüen tudásmegosztásként, hanem azonos időben áramló együttmüködésként és adatvezérelt döntéshozásként. Sőt, krízishelyzetben vagy rendhagyó esetekben akár konkrét válaszokat és felhatalmazást is jelent. A felhatalmazás (többek között Tapscott, 2012) emberek, közösségek, de akár a gépek számára biztosít önállóságot, autoritást és egyben felelősséget. A dinamikus együttmüködéshez ez elengedhetetlen. Azok az aktorok értékelődnek fel, akik problémákat ismernek fel és meg tudják oldani azokat önállóan, vagy konkrét segítséget tudnak kérni a problémamegoldáshoz, avagy tudják, hogyan hozhatnak létre problémamegoldó csoportot.

A konzultáció és kollaboráció leginkább működő platformjai jelenleg az innovációs webhelyek és alkalmazások, a start-up közösségek és meet-upok, az élő laboratoriumok (living labs), a közösségi média egyes témahálózatai és a wikivezérelt folyamatok. Ezek azok a fórumok, melyek alkalmasak az azonnali visszacsatolásra, a nemzetközi vagy lokális szakmai vitára, az edukáció ösztönzésére, a közös felelősséggel és kreativitással létrejövő ökoszisztéma-építésre, a közös tudományos-üzleti-kormányzati kutatások támogatására, a szélesebb társadalmi rétegek érzékenyítésére.

Különösen jól múködnek azok a konzultációs felületek vagy projektek, melyek játékosítva (gamification) vagy vonzó és letisztult dizájnnal érik el célcsoportjukat. A konzultáció ebben az értelemben a funkcionalitás mellett egyben szórakoztatási kategóriává is vált. Kiváló példája a Kaspersky Lab által fejlesztett Earth 2050 platform, mely globálisan elérhető, s különböző szakmák képviselőit, illetve a jövő iránt érdeklődőket egyaránt megszólítja. Kérdése, hogy milyen jövőforgatókönyveket tudunk megfogalmazni és vizuálisan, illetve elemző módon előrevetíteni. A konzultációban résztvevők egyszerre játszanak, sci-fit és valóságot építenek, konzultálnak és a meglévő problémák és kérdések mentén kollaborálnak, illetve problémamegoldásra törekszenek.

Amennyiben ez a konzultációs platform beteljesíti ígéretét, a jövővíziók valósággá válhatnak. A következő lépés e platform szimulációs használata lehet majd - aktív teszteléssel és valósággenerálással. Hipotetikus kérdés, hogy vajon egy kezdetleges mesterséges intelligencia válaszadásai mennyiben müködnének így akár önbeteljesítő jóslatként.

3. ábra

\section{Tudásmegosztásból konzultáció}

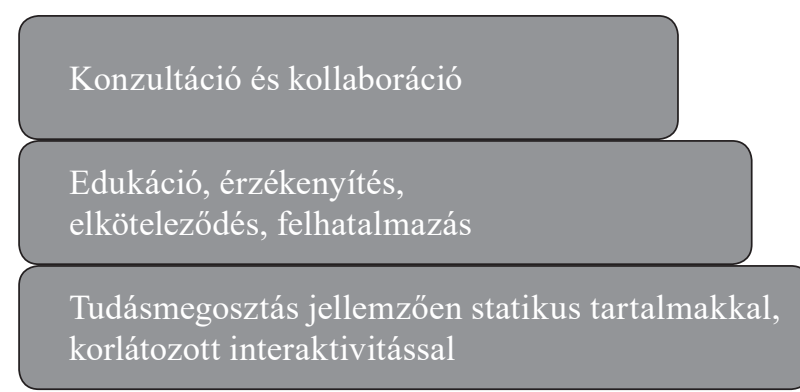

Összefoglalva a fentieket, a tudásmegosztás statikus, lassan változó paradigmájából szükséges váltani a dinamikus konzultációs és kollaborációs együttmüködésekre, átjárva a társadalom, a gazdaság és a kultúra szövetét, edukációval és érzékenyítéssel felépítve a jövő ember-gép alapú, intelligens ökoszisztémáját (lásd 3. ábra).

\section{Zárszó}

A tanulmány célja az volt, hogy röviden értelmezze az okos eszközök és szolgáltatások mérföldkövéről történő átlépést a mesterséges intelligencia korai szakaszába, különös tekintettel a poiltikai és üzleti döntéshozás számára kiemelendő szempontokkal. Megvizsgálva a fenti jelenségeket és kérdéseket, okosról intelligensre átlépés helyett inkább összeérés történik, melynek határvonalai definíciós szinten nem határozhatók meg pontosan. Másfelöl a mesterséges intelligencia mindent átható távlati célja rámutat arra, hogy miért válnak egyes kiemelt helyek és terek - legösszetettebb és egyre jellemzőbb módon a városok - egyfajta ökoszisztémává, ahol digitális ideghálózathoz kapcsolódnak a társadalom, a gazdaság és a politikai döntéshozás vagy döntéstámogatás aktorai. A gyorsuló technológiai fejlődés ebben mindössze alap és eszközrendszer jelenleg az állandó és távlati életminőség-javítás céljával, melynek dinamikus változásait konzultáló és kollaboráló, edukációval és érzékenyítéssel dolgozó interaktivitással és felhatalmazással lehet feloldani, illetve értelmezni - a legmélyebb filozófiai kérdésekig.

A tanulmány ezzel együtt arra is rámutatott, hogy élő laborok és konzultációs platformok helyett a virtuális vagy augmentált valóságoknak egyre komolyabb szerep juthat a jövőtervezésben és az önbeteljesítő jóslatokban a szórakoztatás és a design igénye okán később akár élő laborok helyett élménylaborokkal.

Végül, de nem utolsó sorban a tanulmány számolt olyan következményekkel, melyek az ember-gép szimbiózisból erednek, s a felelősség kérdéseit már az önkritikát tanuló mesterséges intelligencia felől is megvilágítja. A kérdés az, hogy a közeljövőben elérkezik-e a szingularitás, melynek következményeként a változások mértéke már nem lesz felfogható emberi léptékkel, s akkor milyen módon merülnek majd fel az itt feltett etikai és filozófiai kérdések.

Metaanalízissel élve szembenézünk saját teremtményünkkel, amit növesztünk magunk mellett - legyen az egy robot, egy intelligensen reagáló környezet, egy önmagát újraíró vagy szimuláló konzultációs rendszer. Arculata hasonlít ránk, ahogyan egy gyermek is hasonlít a szüleire, ám ahogyan felnő, saját kritikai szempontjaival szembesíthet bennünket.

\section{Felhasznált irodalom}

Arpaci, I. - Baloğlub, M. (2015): The impact of cultural collectivism on knowledge sharing among information technology majoring undergraduates. Computers in Human Behaviour, 56(3), p. 65-71. 
Burgess, A. (2018): The executive guide to artificial intelligence: how to identify and implement applications for AI in your organization. Basingstoke, Hampshire: Palgrave Macmillan

Dameri, R. P. (2017): Smart City Definition, Goals and Performance. In: Smart City Implementation: Creating Economic and Public Value Innovative in Urban Systems. Cham, Switzerland: Springer, p. $1-22$.

Dold, J. - Groopman, J. (2017): The future of geospatial intelligence. Geo-spatial Information Science, 20(2), p. 151-162.

Fehér, K. (2016): Digitalizáció és új média. Trendek, stratégiák, illusztrációk. Budapest: Akadémiai Kiadó

Fehér, K. (2017): Okos város: trendtémák és koncepciók. Információs Társadalom (megjelenés alatt).

Fehér, K. - Király O. (2017): Álhíresülés - a hamis hírek dinamikája a médiában. Századvég, 84(2), p. 39-48.

Ford, M. (2016): Robotok kora. Budapest: HVG.

Goertzel, B. - Ikle, M. - Wigmore, J. (2012): The architecture of human-like general intelligence. In Theoretical Foundations of Artificial General Intelligence, volume 4 of the series Atlantis Thinking Machines. Amsterdam: Atlantis Press, p. 123-144.

Goertzel, B. (2012): What counts as a conscious thinking machine? New Scientist. Elérhető: https:// www.newscientist.com/article/mg21528813.600what-counts-as-a-conscious-thinking-machine/ (Utolsó letöltés 2017. december 22.)

Holthaus, P. - Leichsenring, C. - Richter, V. - Pohling, M. - Carlmeyer, B. - Köster, N. et al. (2016): How to Address Smart Homes with a Social Robot? A Multi-modal Corpus of User Interactions with an Intelligent Environment. In: Language Resources and Evaluation Conference, European Language Resources Association. p. 3440-3446.

Kiulian, A. (2017): Robot is the Boss: How to do Business with Artificial Intelligence. Los Angeles: Amazon DS LCC.

Kurzweil, R. (2006): The Singularity Is Near: When Humans Transcend Biology. NY: Penguin

Lyon, D. (2007): Surveillance studies: An overview. Cambridge: Polity Press Martin, R. (2009) After New Media: Everywhere always on. In. Creeber, G. - Martin, R. (eds): Digital cultures. Understanding New Media. Glasgow: McGraw-Hill, p. 157-163.

Mayer-Schönberger,V. - Cukier, K. V. (2014): Big data. Forradalmi módszer, amely megváltoztatja munkánkat, gondolkodásunkat és egész életünket. Budapest: HVG

Moore, G. E. (1965): Cramming more components to integrated circuits. Electronics, 38(8), p. 114-117.

Mostashari, A. - Arnold, F. - Maurer, M. (2011): Citizens as sensors: The cognitive city paradigm.
Emerging Technologies for a Smarter World (CEWIT). 8th International Conference \& Expo on emerging Technologies for a Smarter World. New York

Muehlhauser, L. (2013): What is AGI? Machine Intelligence Research Institute. Retrieved 1 May 2014. Elérhető: https://intelligence.org/2013/08/11/ what-is-agi/ (Utolsó letöltés: 2017. december 22.)

Nemeslaki A. (2014): E-közszolgálatfejlesztés. Elméleti alapok és tudományos kutatási módszerek. Budapest: Nemzeti Közszolgálati Egyetem

Nilsson, N. J. (2005): Human-Level Artificial Intelligence? Be Serious! American Association for Artificial Intelligence. Elérhetö: http://ai.stanford. edu/ nilsson/OnlinePubs-Nils/General\%20Essays/ AIMag26-04-HLAI.pdf (Utolsó letöltés 2017. december 22.)

Petrolo, R. - Loscri, V. - Mitton, N. (2017): Towards a smart city based on cloud of things, a survey on the smart city vision and paradigms. Transactions on Emerging Telecommunications Technologies, 28(1), p. 1-11.

Seel, P. (2012): Digital Universe: The global telecommunication revolution. Malden, MA: Wiley-Blackwell

Soane, E. - Truss, C. - Alfes, K. - Shantz, A. - Rees, C.Gatenby, M. (2012): Developmentand application of a new measure of employee engagement: the ISA Engagement Scale. Human Resource Development International, 15(5), p. 529-547. Swamynathan, M. (2017): Step 2 - Introduction to Machine Learning. In: Mastering Machine Learning with Python in Six Steps. Berkeley, CA: Apress

Panetta, K. (2017): Top Trends in the Gartner Hype Cycle for Emerging Technologies, 2017. Elérhető: https://www.gartner.com/smarterwithgartner/toptrends-in-the-gartner-hype-cycle-for-emergingtechnologies-2017/ (Utolsó letöltés: 2017. december 22.

Schwab K. (2016): The Fourth Industrial Revolution: what it means, how to respond. World Economic Forum Agenda. [Web:] http://www.weforum.org/ agenda/2016/01/the-fourth-industrial-revolutionwhat-it- means-and-how-to-respond (Utolsó letöltés 2017. december 22.)

Wanigasekara, N. - Schmalfuss, J. - Carlson, D. - Rosenblum, D. S. (2016): A Bandit Approach for Intelligent IoT Service Composition across Heterogeneous Smart Spaces. IoT'16 Proceedings of the 6 th International Conference on the Internet of Things. Stuttgart, Germany, November 7-9. p. 121-129.

Z. Karvalics László (2017): Okos városok, kérdőés felkiáltójelekkel. Szombathely: Felsőbbfokú Tanulmányok Intézete

Zhang, $X$. Q. (2016): The trends, promises and challenges of urbanisation in the world. Habitat International, 54(3), p. 241-252. 


\section{Üzleti trendriportok, projektek, előadások}

Edson, B. by Microsoft (2015) Creating the internet of your things. Elérhetö: www. InternetOfYourThings. com by Microsoft

Ericsson Consumer Lab (2015) 10 hot consumer trends. Elérhetö: http:/www.ericsson.com/ res/ docs/2014/consumerlab/ericsson-consumerlab-10hot-consumer-trends-2015.pdf

Huawei (2016) Global Connectivity Index. Elérhető: www.huawei.com
McKinsey \& Company (2015) The internet of things: Mapping the value beyond the hype. Elérhetö: http://www.mckinsey.com/insights/business technology (Utolsó letöltés 2017. december 22.)

Tapscott, D. (2012) Four principles for the open world. Elérhető: https://www.ted. com/talks/don_tapscott_four_principles for_the_ope $\bar{n}_{-}$world_ 1 ? language $=$ e $\bar{n}$

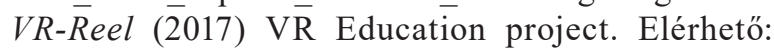
http://www.vr-reel.com 